\title{
INVESTIGATION OF AWARENESS OF ROTAVIRUS INFECTION AND VACCINATION IN PARENTS OF INFANTS LESS THAN ONE YEAR-A QUESTIONNAIRE STUDY FROM TURKEY
}

\author{
Önder Kılıçaslan, Muhammet Mesut Nezir Engin, Merve Aslantaş, Furkan Timur, Kenan \\ Kocabay
}

Düzce University, School of Medicine, Department of Pediatrics, Düzce, Turkey.

${ }^{*}$ Corresponding author: dronderklcsln@gmail.com

\begin{abstract}
Introduction: Rotavirus infection is one of the most common causes of infantile diarrhea, with significance in developing countries where it accounts for $15-30 \%$ of the mortality rate. Vaccination is an effective way to prevent disease and mortality. Therefore, parents' knowledge about Rotavirus infection and vaccination is critical in increasing vaccination rates. We aimed to investigate parental awareness about Rotavirus infection and vaccine, evaluate attitudes towards Rotavirus vaccination, and determine factors affecting acceptance and hesitations about immunization. Methods: This survey included 1856 participants: parents who had a child aged under one year of age. A self-explanatory questionnaire consisting of 13 questions was composed to determine parental awareness and behavior regarding Rotavirus infection and the vaccine. Results: More than half $(n=541,58.30 \%)$ of the parents knew that diarrhea could be a fatal disease, less than half ( $n=354,38.15 \%)$ knew that RV could cause diarrhea. The parental knowledge rates about the Rotavirus infection and the vaccine were positively correlated with parents' education level and monthly family income. Less than half $(41.59 \%)$ of the parents were found to have vaccinated their children for Rotavirus infection. Vaccination rates increased in parallel with the increase in income and education level of parents. The primary reasons for nonvaccination were lack of knowledge (44.83\%) and the fear of possible side effects $(14.94 \%)$. Conclusion: The present survey demonstrates that parents' knowledge of rotavirus vaccination is not adequate, and the rate of rotavirus vaccination is even low. The present study underlines that health providers are critical insufficient society awareness and acceptance of Rotavirus immunization.
\end{abstract}

Keywords: Awareness, parents, rotavirus vaccination 


\section{Introduction}

Rotavirus (RV) is the most common cause of severe gastroenteritis (GE) worldwide in children $<5$ years of age in countries that have not adopted the universal use of $R V$ vaccines. However, the infection rate has been decreased in the countries that have successfully vaccinated a large proportion of infants against RV (O'Ryan et al.,2015). Although recurrent infection is usually asymptomatic or mild to moderate among older children and adults, it can be severe in a subdivision and may lead to death in infants (Rana et al.,2021).

The viral RVGE is transmitted via the fecal-oral route and has an incubation period of fewer than 48 hours. There is no specific treatment protocol for viral GE in children; the general approach is supportive and supplementary treatment. The RV vaccine is the most effective way to prevent RVGE in children (Burnett et al.,2020).

Since 2013 The World Health Organization (WHO) has recommended including RV vaccines into national vaccination programs and lists them in the Essential Medicines List (WHO,2013). Interestingly, the $R V$ vaccination rate is around $25 \%$ in some countries; despite that, the $R V$ vaccination has been introduced into the routine vaccination program (Giaquinto et al.,2011). Rotarix and RotaTeq vaccines are safe and effective vaccines approved for clinical use in Turkey. These vaccines are equivalent in terms of safety, effectiveness, and cost. These vaccines have strict age recommendations for administration: the first dose should be given before 15 weeks of age, and all doses must be provided by eight months. When this study was conducted, Turkish Health Ministry has not raised the RV vaccination in the standard vaccination program, and the routine national childhood immunization program does not cover it. Therefore, Turkey statistic reports project that $\mathrm{RV}$ vaccination rates are relatively minimal in Turkey.

The present study aimed to evaluate parents who have an infant child from the awareness and behaviors aspect for RV infection. The main aim of this study was to consider what determinants affect vaccination decision or hesitation. The outcomes of this study may guide strategies to increase population immunity gains $R V$ infection.

\section{Methods}

\section{Recruitment and Data Collection}

The present study is a six-month study conducted between January 01,2018 , and July 01,2018 , in the pediatric outpatient clinic of the Department of Pediatric Health and Diseases, University Faculty of Medicine, Düzce, Turkey. A total of 1856 parents who have a child under one year of age were involved. The parents of the children who had been admitted to the Emergency Department for an acute illness, those previously informed of the RV vaccines at our department, and who had a child older than one year were excluded from the study. 


\section{Study design}

It is a descriptive cross-sectional study. A self-explanatory questionnaire was designed with the help of the medical statistics department. We enclosed all the patients aged under one year, admitting to the outpatient policlinic sequentially; no maximum sample size was required. All the parents signed informed consent before participating in the study.

\section{Development of survey instruments}

To quaternate the study groups, a self-explanatory questionnaire was designed; it was comprised of 13 questions it assessed parents' awareness, knowledge, and behaviors regarding RVGE and RV vaccines. The questionnaire was completed under observation without any intervention. It included questions that queried parents on the following:

- Demographics: age, gender, education, socioeconomic status,

- Knowledge of GE-related mortality, RV-related GE, RV vaccines,

- Attitude and behavior regarding RV vaccination and also reasons for hesitation regarding the use of RV vaccines,

- The source of their knowledge regarding the topics questioned.

\section{Ethical Issues}

The regional scientific ethics committee approved the study following the World Medical Association Declaration of Helsinki: Ethical Principles for Medical Research Involving Human Subjects.

\section{Statistical Analysis}

All analyses were performed on SPSS v21. Data are given median (minimum-maximum) for continuous variables and frequency (percentage) for categorical variables. The utilization of Chi-square tests performed categorical comparisons. $\mathrm{P}<0.05$ values were defined as the significance level for all statistical analyses.

\section{Results}

\section{Study Population}

Our study included 1856 parents (926 males and 926 females). Mothers' median age was 28 (17-45) years, $308(33.2 \%)$ of the mothers had graduated from high school, and $695(74.9 \%)$ were housewives. The fathers' median age was 32 (19-56) years, $334(36 \%)$ of the fathers had graduated from high school, and 561 (60.45\%) had working-class jobs. Among the 926 families, 442 (47.7\%) had 250-500 USD income per month. The median age of the children was 79.5 (1-350) days, and 428 of the children 
$(46.1 \%)$ were girls, $500(53.9 \%)$ were boys. The summary of parent and child-related characteristics is presented in Table 1.

\begin{tabular}{|l|l|}
\hline \multicolumn{2}{|l|}{ Table 1. Summary of Parent and Child Characteristics } \\
\hline Child Age (Day) [Median, min-max] & $79.5(1-350)$ \\
\hline Gender & \\
\hline Girl (n) & $428(46.12 \%)$ \\
\hline Boy (n) & $500(53.88 \%)$ \\
\hline Mother Age (median, min-max) & $28(17-45)$ \\
\hline Mother Education Status & \\
\hline Illiterate & $28(3.02 \%)$ \\
\hline Primary school & $187(20.15 \%)$ \\
\hline Secondary school & $212(22.84 \%)$ \\
\hline High school & $308(33.19 \%)$ \\
\hline University & $193(20.80 \%)$ \\
\hline Mother Occupation & \\
\hline Housewife & $695(74.89 \%)$ \\
\hline Worker & $103(11.10 \%)$ \\
\hline Officer & $111(11.96 \%)$ \\
\hline Others & $19(2.05 \%)$ \\
\hline Father Age (median, min-max) & $32(19-56)$ \\
\hline Father Education Status & \\
\hline Illiterate & $4(0.43 \%)$ \\
\hline Primary school & $119(12.82 \%)$ \\
\hline Secondary school & $200(21.55 \%)$ \\
\hline High school & $334(35.99 \%)$ \\
\hline University & $271(29.20 \%)$ \\
\hline Father Occupation & \\
\hline Unemployed & $35(3.77 \%)$ \\
\hline Working-Class Job & $561(60.45 \%)$ \\
\hline Civil Servant & $257(27.69 \%)$ \\
\hline Others & $75(8.08 \%)$ \\
\hline Income (Monthly, USD) & $204(21.98 \%)$ \\
\hline < 250 & $442(47.63 \%)$ \\
\hline $250-500$ & $282(30.39 \%)$ \\
\hline$>500$ & \\
\hline $\begin{array}{l}\text { Data given as median (minimum-maximum) for continuous variables and frequency } \\
\text { (percentage) for categorical variables }\end{array}$ \\
\hline & \\
\hline & \\
\hline & \\
\hline & \\
\hline
\end{tabular}

\section{Parental Awareness Data}

When information about RVGE was questioned, although more than half ( $n=541,58.30 \%$ ) of the parents knew that diarrhea could be a fatal disease, less than half ( $n=354,38.15 \%)$ knew that RV could cause diarrhea. When knowledge about the RV vaccine was questioned, it was found that more than half $(n=528,56.90 \%)$ of the parents declared that they knew diarrhea was a vaccine-preventable disease. However, less than one-third ( $n=265,28.56 \%$ ) had any knowledge about the RV vaccine. The results regarding parents' knowledge about RV infection are presented in figure 1. 


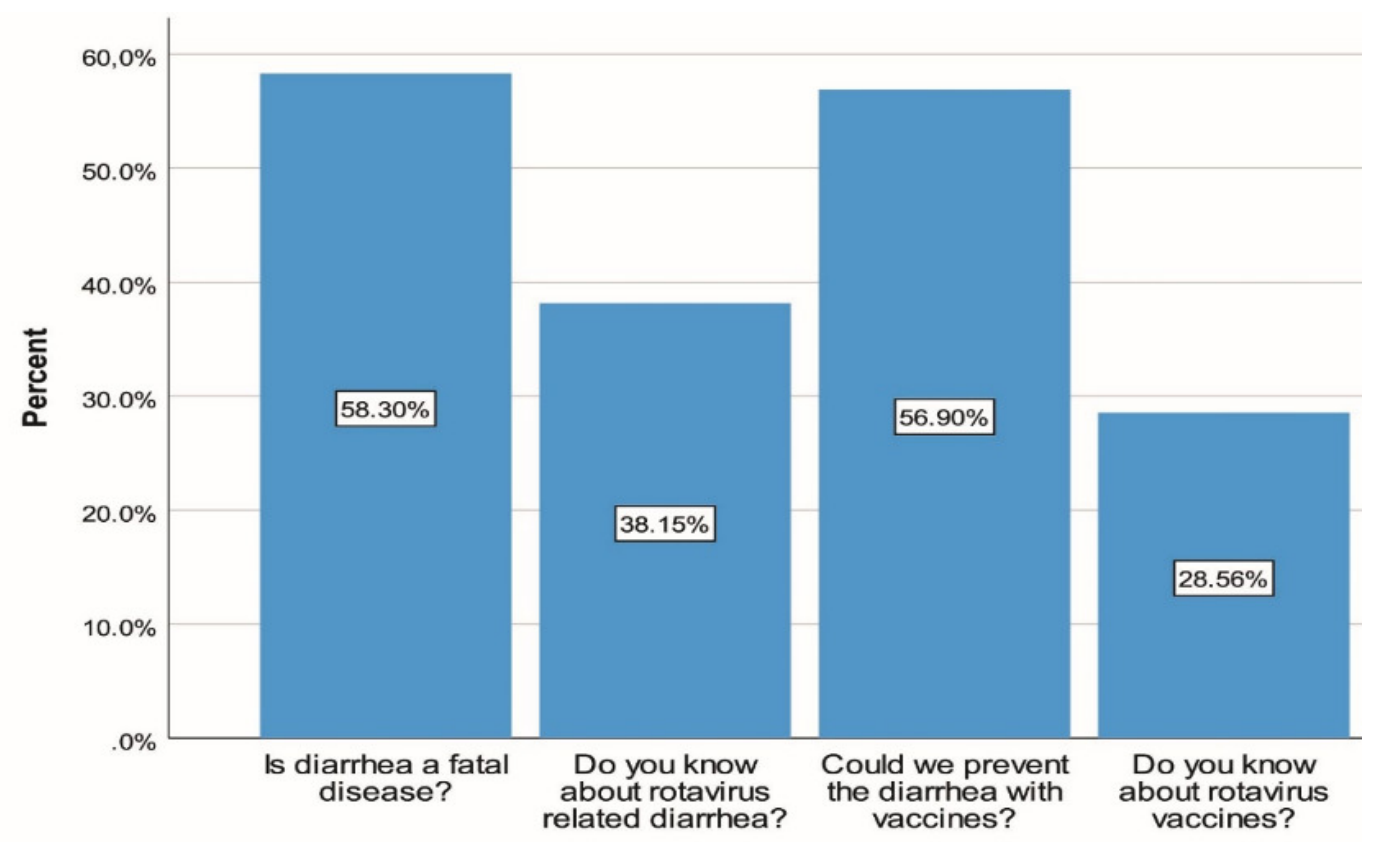

Figure 1: The results regarding the knowledge of parents about RV infection

Univariate analysis showed that, when both parents possessed a university degree, they were significantly more likely to have correct knowledge regarding the following statements: 'Diarrhea can be a fatal disease' (mothers $n=14072.54 \%, p<0.001$, fathers $n=18267.16 \%, p=0.002$ ), 'RV infection is associated with diarrhea' (mothers $n=13569.95 \%, p<0.001$, fathers $n=16761.62 \%, p<0.001$ ), 'Diarrhea can be prevented with vaccination' (mothers $n=15077.72 \%, p<0.001$, fathers $n=19471.59 \%, p<0.001$ ). Also, these parents had significantly higher knowledge levels about RV vaccines (mothers $n=104$ $53.89 \%, p<0.001$, fathers $n=14051.66 \%, p<0.001$ ) (Table 2 and 3 ).

When the knowledge level of the parents was evaluated according to the monthly income, it was seen that those with a monthly income of 500 USD or higher had more information about RVGE and RV vaccines (diarrhea can be a fatal disease; $\mathrm{n}=17963.48 \%, \mathrm{p}=0.016$, $\mathrm{RV}$ infection is associated with diarrhea; $n=17461.70 \%, p<0.001$, diarrhea can be prevented with vaccination; $n=19970.57 \%$, $p<0.001$, and better knowledge about RV vaccines; $n=14250.35 \%, p<0.001$ ) (Table 2 and 3). 
Table 2. Summary of answers regarding mother's education status and comparison results

\begin{tabular}{|c|c|c|c|c|c|}
\hline & $\begin{array}{c}\text { Primary or } \\
\text { less }\end{array}$ & Secondary & High School & University & $p$ \\
\hline $\mathbf{N}$ & 215 & 212 & 308 & 193 & N.A \\
\hline \multicolumn{6}{|l|}{$\begin{array}{l}\text { Can diarrhea be a fatal } \\
\text { disease? }\end{array}$} \\
\hline Yes & $109(50.70 \%) \mathrm{a}$ & $\begin{array}{c}117(55.19 \%) \\
a \\
\end{array}$ & $\begin{array}{c}175(56.82 \%) \\
a \\
\end{array}$ & $\begin{array}{c}140(72.54 \%) \\
b \\
\end{array}$ & \multirow[t]{2}{*}{$<0.001$} \\
\hline No & $106(49.30 \%)$ & $95(44.81 \%)$ & $133(43.18 \%)$ & $53(27.46 \%)$ & \\
\hline \multicolumn{6}{|l|}{$\begin{array}{l}\text { Do you know about } \\
\text { rotavirus-related diarrhea? }\end{array}$} \\
\hline Yes & $46(21.40 \%) a$ & $45(21.23 \%) \mathrm{a}$ & $\begin{array}{c}128(41.56 \%) \\
b\end{array}$ & $\begin{array}{c}135(69.95 \%) \\
\mathrm{C}\end{array}$ & \multirow[t]{2}{*}{$<0.001$} \\
\hline No & $169(78.60 \%)$ & $167(78.77 \%)$ & $180(58.44 \%)$ & $58(30.05 \%)$ & \\
\hline \multicolumn{6}{|l|}{$\begin{array}{l}\text { Can diarrhea be prevented } \\
\text { with vaccination? }\end{array}$} \\
\hline Yes & $99(46.05 \%) a$ & $95(44.81 \%) \mathrm{a}$ & $\begin{array}{c}184(59.74 \%) \\
b\end{array}$ & $\begin{array}{c}150(77.72 \%) \\
\mathrm{C} \\
\end{array}$ & \multirow[t]{2}{*}{$<0.001$} \\
\hline No & $116(53.95 \%)$ & $117(55.19 \%)$ & $124(40.26 \%)$ & $43(22.28 \%)$ & \\
\hline \multicolumn{6}{|l|}{$\begin{array}{l}\text { Do you know about rotavirus } \\
\text { vaccines? }\end{array}$} \\
\hline Yes & $31(14.42 \%) a$ & $30(14.15 \%) a$ & $\begin{array}{c}100(32.47 \%) \\
b\end{array}$ & $\begin{array}{c}104(53.89 \%) \\
\mathrm{c} \\
\end{array}$ & \multirow[t]{2}{*}{$<0.001$} \\
\hline No & $184(85.58 \%)$ & $182(85.85 \%)$ & $208(67.53 \%)$ & $89(46.11 \%)$ & \\
\hline
\end{tabular}

Chi-square test. The same letter denotes a lack of significant difference between groups.

Data are given as frequency (percentage)

Table 3. Summary of answers regarding father's education status and comparison results

\begin{tabular}{|c|c|c|c|c|c|}
\hline & $\begin{array}{l}\text { Primary or } \\
\text { less }\end{array}$ & $\begin{array}{l}\text { Secondar } \\
y\end{array}$ & $\begin{array}{l}\text { High } \\
\text { School }\end{array}$ & University & $\mathbf{p}$ \\
\hline $\mathbf{N}$ & 123 & 200 & 334 & 271 & N.A \\
\hline \multicolumn{6}{|l|}{ Can diarrhea be a fatal disease? } \\
\hline Yes & $\begin{array}{l}68 \\
(55.28 \%) \mathrm{a}\end{array}$ & $\begin{array}{l}101 \\
(50.50 \%) \mathrm{a}\end{array}$ & $\begin{array}{l}190 \\
(56.89 \%) \mathrm{a}\end{array}$ & $\begin{array}{l}182 \\
(67.16 \%) b\end{array}$ & \multirow[t]{2}{*}{$\begin{array}{l}0.00 \\
2\end{array}$} \\
\hline No & $\begin{array}{l}55 \\
(44.72 \%)\end{array}$ & $\begin{array}{l}99 \\
(49.50 \%)\end{array}$ & $\begin{array}{l}144 \\
(43.11 \%)\end{array}$ & $\begin{array}{l}89 \\
(32.84 \%)\end{array}$ & \\
\hline \multicolumn{6}{|c|}{$\begin{array}{l}\text { Do you know about rotavirus- } \\
\text { related diarrhea? }\end{array}$} \\
\hline Yes & $\begin{array}{l}28 \\
(22.76 \%) \mathrm{a}\end{array}$ & $\begin{array}{l}59 \\
(29.50 \%) \mathrm{a}\end{array}$ & $\begin{array}{l}100 \\
(29.94 \%) a\end{array}$ & $\begin{array}{l}167 \\
(61.62 \%) b\end{array}$ & \multirow[t]{2}{*}{$\begin{array}{l}<0.0 \\
01\end{array}$} \\
\hline No & $\begin{array}{l}95 \\
(77.24 \%)\end{array}$ & $\begin{array}{l}141 \\
(70.50 \%)\end{array}$ & $\begin{array}{l}234 \\
(70.06 \%)\end{array}$ & $\begin{array}{l}104 \\
(38.38 \%)\end{array}$ & \\
\hline \multicolumn{6}{|c|}{$\begin{array}{l}\text { Can diarrhea be prevented with } \\
\text { vaccination? }\end{array}$} \\
\hline Yes & $\begin{array}{l}60 \\
(48.78 \%) \mathrm{a}\end{array}$ & $\begin{array}{l}103 \\
(51.50 \%) \mathrm{a}\end{array}$ & $\begin{array}{l}171 \\
(51.20 \%) \mathrm{a}\end{array}$ & $\begin{array}{l}194 \\
(71.59 \%) b\end{array}$ & \multirow[t]{2}{*}{$\begin{array}{l}<0.0 \\
01\end{array}$} \\
\hline No & $\begin{array}{l}63 \\
(51.22 \%)\end{array}$ & $\begin{array}{l}97 \\
(48.50 \%)\end{array}$ & $\begin{array}{l}163 \\
(48.80 \%) \\
\end{array}$ & $\begin{array}{l}77 \\
(28.41 \%)\end{array}$ & \\
\hline \multicolumn{6}{|c|}{$\begin{array}{l}\text { Do you know about rotavirus } \\
\text { vaccines? }\end{array}$} \\
\hline Yes & $\begin{array}{l}20 \\
(16.26 \%) \mathrm{a}\end{array}$ & $\begin{array}{l}43 \\
(21.50 \%) \mathrm{a}\end{array}$ & $\begin{array}{l}62 \\
(18.56 \%) \mathrm{a}\end{array}$ & $\begin{array}{l}140 \\
(51.66 \%) b\end{array}$ & \multirow[t]{2}{*}{$\begin{array}{l}<0.0 \\
01\end{array}$} \\
\hline No & $\begin{array}{l}103 \\
(83.74 \%)\end{array}$ & $\begin{array}{l}157 \\
(78.50 \%)\end{array}$ & $\begin{array}{l}272 \\
(81.44 \%)\end{array}$ & $\begin{array}{l}131 \\
(48.34 \%)\end{array}$ & \\
\hline
\end{tabular}




\section{Parental Attitudes for Vaccination Data}

When RV vaccination behaviors were questioned, less than half $(n=386,41.6 \%)$ of the parents reported that they had vaccinated their child. However, as the income level and education level increased, it was found that vaccination rates increased (income $>500$ USD; $n=167,59.22 \%, p<0.001$ ). The primary cause of hesitancy among parents regarding $R V$ vaccinations was: lack of knowledge ( $n=243,44.8 \%)$, concerns about side effects ( $n=81,14.9 \%)$, no specific reason $(n=62,11.4 \%)$, being unable to decide without asking the opinion of their spouse $(n=58,10.7 \%)$, believing there would be no benefit $(n=52$, $9.6 \%)$, and being unable to obtain the vaccine due to cost ( $n=46,8.5 \%)$ (Figure 2).

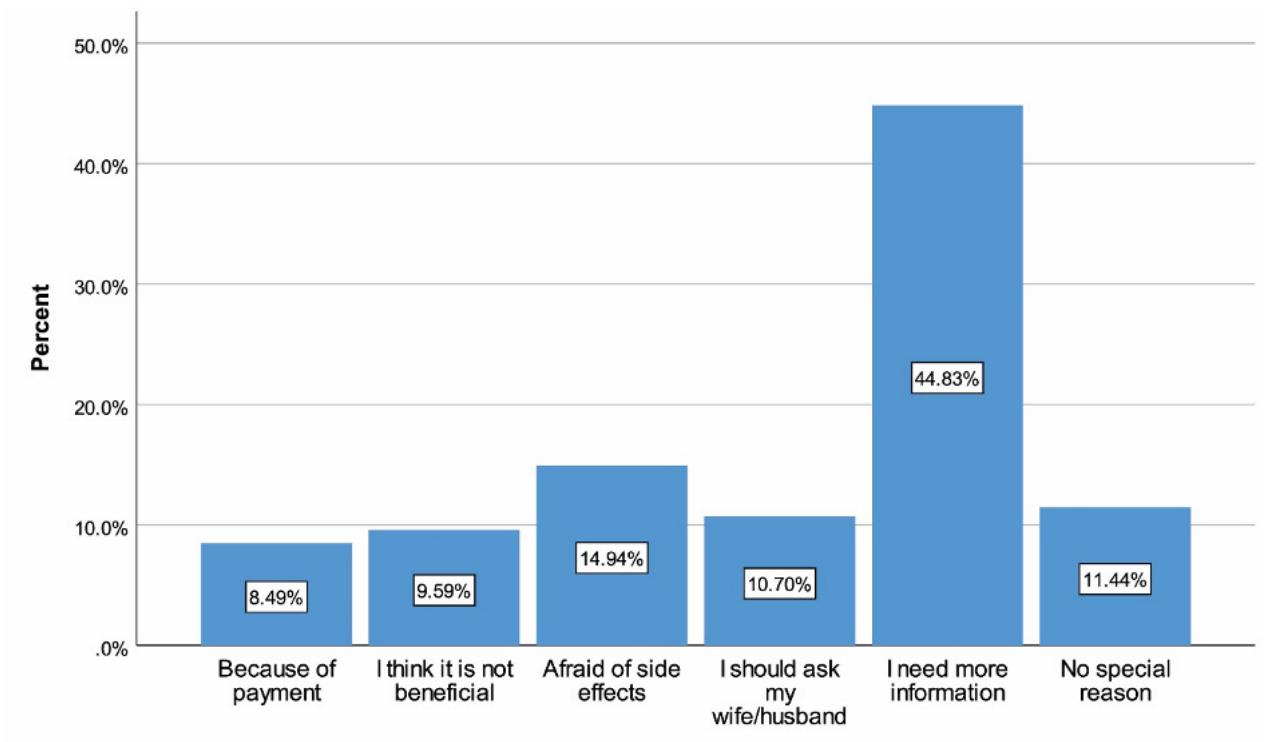

Figure 2: The primary cause of hesitancy among parents regarding RV vaccinations

\section{Sources of Information Data}

The most common sources of information about RVGE and RV vaccines among mothers and fathers were: health professionals ( $n=169,47.7 \%$ and $n=150,56.6 \%$, respectively) and television/internet ( $n=$ $169,47.7 \%$ and $n=6725.3 \%)$, followed by friend/family sources $(n=77,21.8 \%$ and $n=48,18.1 \%)$.

\section{Discussion}

This is not the only but one of the most comprehensive studies that had assessed the awareness, and knowledge levels of parents of children under one year of age, about RV infection, attitudes towards vaccination, and the determinants that affect immunization preference in Turkey. We can summarize our results as follows: the knowledge level of GE mortality, RV infection, and RV vaccination was insufficient among parents of infants. Lack of knowledge on $\mathrm{RV}$ vaccination and fear of its probable side effects were the main reasons for vaccination hesitation established in our study. 
More than half of the study participants claimed that they knew about the mortality risk of gastroenteritis $(58.3 \%)$. Interestingly, mothers were meaningfully more aware of gastroenteritis mortality than fathers. Again, the majority have stated that they were aware of the prevention of the disease via vaccination (56.9\%). Besides, few participants were aware of RV infection as diarrhea pathogenesis $(38.2 \%)$, and even less knew it is preventable by vaccination (28.56\%). On these topics of knowledge, there was no difference between mothers and fathers.

When we examined the articles on RV infection published in Turkey, we determined that, in recent years, the parental awareness rates of vaccination and the $R V$ infection itself are higher than the studies conducted in previous years. For example, in their study presented in 2010 and 2011, the awareness rates of RV infection and medical prevention Köksal et al. $(2013,2016)$ reported $19.2 \%$ and $24.8 \%$, respectively. And, the later studies, published in 2020, Ayyıldız et al. (2020) reported the rate as $51.1 \%$, and Cıklar \& Güner (2020) reported the rate of the parent who has and adequate information of RV infection and vaccination as $4.5 \%$. Again, Cıklar \& Güner (2020) claimed that the RV vaccine is among Turkish mothers' most known self-paid vaccines. We suppose that this may be due to the increased recommendation of the $\mathrm{RV}$ vaccine in recent years and its prevalence.

This data should encourage increasing population awareness on RV and medical prevention. Considering that RV infection is a successfully preventable disease that may cause a significant mortality rate, it is essential to take necessary precautions for the government.

\section{Parental Intention and Hesitations to Immunize their Child Against Rotavirus}

In their study, Bulbul et al. (2013) found the rate of RV vaccination to be $.007 \%$. Cıklar \& Güner (2020) reported that $27.7 \%$ of parents vaccinated their children against RV infection. In our study, the vaccination rate was found to be $41.6 \%$. Chronological studies have shown that the rate of RV vaccination is low. Although the application rate of the $R V$ vaccine is low in this study compared to those reported from some European and developed countries, it was observed that vaccination rates against RV remarkably increase compared to previous years (Van Damme et al.,2006; Dubé et al.,2012). As proved above, we suppose this satisfactory progress is due to the increased awareness of vaccination against RV in Turkey.

Similar to the data above about awareness of RV infection and vaccination, the most critical parental characteristics affecting the willingness for vaccination rate were education level and family income. Vaccination rates were positively correlated with higher education and monthly income. Both the international and the Turkish literature reports support our findings that education and family income levels affect the rates of immunization willingness (Cıklar \& Güner,2020; Odabaş \& Ayyildiz, 2020). 
Our study has introduced some points determining parental intention and hesitation about vaccination. The most common cause was lack of knowledge (44.8\%). The next following causes were concerns about side effects $(14.9 \%)$, no specific reason $(11.4 \%)$, being unable to decide without asking the opinion of their spouse $(n=58,10.7 \%)$, expecting no benefit $(9.6 \%)$, and cost $(8.5 \%)$ respectively. What is the data on this concern in the medical literature? The Turkish studies claim that lack of information, or even not have been heard of the presence of the RV vaccine, is above $80 \%$; these are the studies conducted in 2016 and 2020 (Cıklar \& Güner,2020; Kaçmaz et al.,2016). Similar rates of causes for non-vaccination were reported from European studies; in the low non-vaccinated rates, the most common reason was the lack of knowledge (Van Damme et al.,2006; Della Polla et al.,2020). What is the outcome we benefit from this finding? First, wide-spreading and increasing the knowledge levels of $\mathrm{RV}$ and the vaccine are obliged to be a public health destination. Literature directs us that the RV vaccine provides herd immunity, indicating that increasing $R V$ vaccination rates may provide significant advantages in child health, disease burden, and healthcare expense (Mast et al.,2015; Seybolt \& Bégué.,2012).

\section{Parental Sources of Information about Rotavirus Infection and Immunization}

In the present study, we determined that the most common parental source, the RV infection, and the vaccine were health providers with the highest rate, followed by internet and television sources, and in minor rate followed by environmental and friend authorities. In previous studies, similar to this, it was determined that information about vaccines was obtained from health personnel at a high rate (Cıklar \& Güner,2020; Dubé et al.,2012). Relying upon this consequence, health providers must make broader and further plans to raise public acknowledgment of $R V$ and the vaccine. Again, public announcements via various media and television broadcasts are essential in increasing public vaccination acceptance.

As a result, parents' knowledge of $R V$ vaccination was low, and the rate of $R V$ vaccination was even lower. The leading causes for not vaccinating were unaware of the vaccine, lack of knowledge, financial inability, and the fear of possible side effects of the vaccine. The study observed that as the parents' education level increased, the knowledge rate of the RV and RV vaccine and immunization rates increased. It was determined that the most important information source about the RV vaccine was the health providers.

\section{Study Limitations}

This is a self-declared survey; therefore, the data is subjective and may not provide the accurate status of vaccination of the children. The other limitation of this study is that it was conducted in a singlecenter, one concrete tertiary healthcare center, which may not represent the whole population. Nevertheless, the high number of survey participants increases the value of the study and the importance of our research. 


\section{Conclusion}

Vaccination plays a significant role in preventing RV infections and reducing disease-related mortality and morbidity in our country. Therefore, we suggest having an information policy for parents about RV infection and immunization during routine vaccination admission; it may be provided by trained health care providers or with introductory brochures. Besides, the most critical factor in increasing the rate of $R V$ vaccination is that the Ministry of Health includes the $R V$ vaccine in the childhood routine vaccination program in Turkey.

\section{Conflicts of Interest}

The author declares no conflicts of interest.

\section{References}

- Ayyildiz T, Altintaş HK, Aydin C, Minaz E, Yörük T. (2020). 0-5 Yaş Çocuklarda Rotavirüs Sıklığı ve Anne-Babaların Rotavirüse Yönelik Bilgi Düzeyleri ve Uygulamaları. Dokuz Eylül Üniversitesi Hemşirelik Fakültesi Elektronik Dergisi, 13(3), 124-130.

- Bulbul M, Ergüven M, Yasa O, Tombalak NA. (2013). Sağlam çocuk polikliniğimize başvuran çocukların rutin aşı ve diğer aşıların uygulama oran ve düzeninin değerlendirilmesi. Göztepe Tıp Dergisi, 28(4), 171-178. doi: 10.5222/J.GOZTEPETRH.2013.171

- Burnett E, Parashar UD, Tate JE. (2020). Real-world effectiveness of rotavirus vaccines, 200619: a literature review and meta-analysis. Lancet Glob Health, 8(9), e1195-e202. doi: 10.1016/S2214-109X(20)30262-X

- Cıklar S \& Güner PD. (2020). Annelerin çocukluk çağı aşıları hakkındaki bilgi, davranış ve tutumları ve aşı reddi nedenleri: Nitel ve nicel bir araştırma. Ankara Medical Journal, 20(1), 180195. doi: $10.5505 / a m j .2020 .80148$

- Della Polla G, Napolitano F, Pelullo CP, De Simone C, Lambiase C, Angelillo IF. (2020). Investigating knowledge, attitudes, and practices regarding vaccinations of community pharmacists in Italy. Hum Vaccin Immunother, 16(10), 2422-2428. doi: 10.1080/21645515.2020.1720441

- Dubé E, Bettinger J, Halperin B, Bradet R, Lavoie F, Sauvageau C, Gilca V, Boulianne N. (2012). Determinants of parents' decision to vaccinate their children against rotavirus: results of a longitudinal study. Health Educ Res, 27(6), 1069-1080. doi: 10.1093/her/cys088

- Giaquinto C, Dominiak-Felden G, Van Damme P, Myint TT, Maldonado YA, Spoulou V, Mast TC, Staat MA. (2011). Summary of effectiveness and impact of rotavirus vaccination with the oral pentavalent rotavirus vaccine: A systematic review of the experience in industrialized countries. Human Vaccin, 7(7), 734-748. doi: 10.4161/hv.7.7.15511

- Kaçmaz Ersü N, Ersü A, Öztürk YK, Helvacı M, Öngel K. (2016). Gastroenterit tanısı ile hastanede yatan çocukların özellikleri ve ebeveynlerin rotavirüs aşısı hakkındaki bilgi düzeyleri. Journal of $\mathrm{Dr}$ Behcet Uz Children's Hospital, 6(3), 203-208. doi: 10.5222/buchd.2016.203Koksal T, Akelma AZ, Koksal AO, Kutukoglu I, Ozdemir O, Yuksel CN, Bozkaya D, Catal F, Sari S. (2017). Cost-effectiveness of rotavirus vaccination in Turkey. J Microbiol Immunology Infect, 50(5), 693-699. doi: 10.1016/j.jmii.2016.03.005 
- Koksal AO \& Köksal T. (2013). Ankara'da 0-5 yaş arası akut gastroenteritli çocuklarda rotavirus sıkığı. Yeni Tıp Dergisi, 30(2), 121-123.

- Mast TC, Wang FT, Su S, Seeger JD. (2015). Evidence of herd immunity and sustained impact of rotavirus vaccination on the reduction of rotavirus-related medical encounters among infants from 2006 through 2011 in the United States. Pediatr Infect Dis J, 34(6), 615-620. doi: 10.1097/INF.0000000000000702

- Parez N, Giaquinto C, Du Roure C, Martinon-Torres F, Spoulou V, Van Damme P, Vesikari T. (2014). Rotavirus vaccination in Europe: drivers and barriers. Lancet Infect Dis, 14(5), 416-425. doi: 10.1016/S1473-3099(14)70035-0

- Odabaş N \& Ayyildiz T. (2020). Anne Babaların Çocukluk Dönemi Aşılarına Yönelik Bilgi ve Uygulamalarının Değerlendirilmesi. Med J West Black Sea, 4(1), 7-11. doi: 10.29058/mjwbs.2020.1.2

- O'Ryan M, Giaquinto C, Benninghoff B. (2015). Human rotavirus vaccine (Rotarix): focus on effectiveness and impact 6 years after first introduction in Africa. Expert review of vaccines, 14(8), 1099-1112. doi: 10.1586/14760584.2015.1059282

- Rana R, Dahiphale R, Kalrao V. (2021). Epidemiological and Clinical Profile of Rotavirus Gastroenteritis among Children Younger than 5 Years of Age. Indian J Child Health, 8(1), 4650. doi: 10.32677//JCH.2021.v08.i01.009

- Seybolt LM \& Bégué RE. (2012). Rotavirus vaccination and herd immunity: an evidence-based review. Pediatric Health, Medicine and Therapeutics, 3, 25-37. doi: 10.2147/PHMT.S25705

- Simpson E, Wittet S, Bonilla J, Gamazina K, Cooley L, Winkler JL. (2007). Use of formative research in developing a knowledge translation approach to rotavirus vaccine introduction in developing countries. BMC Public Health, 7, 281. doi: 10.1186/1471-2458-7-281

- WHO position paper. (2013). Rotavirus vaccines. Wkly Epidemiol Rec, 88(5), 49-64. Retrieved 1 June 2021, from https://apps.who.int/iris/handle/10665/242024

- Van Damme P, Van der Wielen M, Ansaldi F, Desgrandchamps D, Domingo JD, Sanchez FG, Gray J, Haditsch M, Johansen K, Lorgelly P, Lorrot M, Parez N, Reschke V, Rose M. (2006). Rotavirus vaccines: considerations for successful implementation in Europe. Lancet Infect Dis, 6(12), 805-812. doi: 10.1016/S1473-3099(06)70657-0 